\title{
State Aid and COVID-19 - Hot Topics
}

\author{
Setting the Scene
}

This edition of EStAL includes a special focus on State aid and COVID-19. Although EStAL $2 / 2020$ also covers other interesting topics that I encourage you to go through, I will devote my editorial to the issue that has gripped the State aid community - the corona pandemic.

To set the scene: on 31 January 2020, the first two cases of COVID-19 were confirmed in Rome. The first COVID-19 related death occurred on 1 March - again in Italy. As of 13 March 2020, the WHO began to consider Europe the active centre of the pandemic.

The first aid measure to address the crisis was approved on 12 March. It had been notified 24 hours earlier by Denmark and concerned a $€_{12}$ million scheme to compensate event organisers cancelling large events. It was approved under Article 107(2)(b) TFEU allowing for crisis aid in extraordinary circumstances.

The next day, on 13 March, the Commission issued a Coordinated Response on Coronavirus, announcing eg the suspension of the EU rules on airport slots (the $80 \%$ 'use-it-or-lose-it' rule), putting an end to airplanes flying around with empty seats.

Just six days later, on 19 March, the Commission issued its COVID-19 Guidelines (Temporary Framework or TF) on how to handle aid notified under Article 107(3)(b) TFEU concerning aid 'to remedy a serious disturbance in the economy of a Member State'. The first decision based on the TF - concerning a Danish loan guarantee scheme - was adopted on 21 March, only 48 hours after the adoption of the TF.

On 12 June, precisely three months after the adoption of its first decision, the Commission had adopted 159 decisions approving 196 national measures notified by 26 Member States and the United Kingdom. The approved aid amounts are estimated to total some $€_{2.2}$ trillion (including loans and guarantees). Germany reportedly accounts for some $45 \%$ of all aid granted. The vast majority of decisions have been adopted under the TF.

\section{'Constructing the Railway With the Train Already on It'}

The number of decisions and the decision time of the Commission are breathtaking and unprecedented. The Commission should be - and indeed has been - widely commended for its flexibility, responsiveness and pragmatism, allowing aid to be dispensed with almost immediate effect. This has happened with most Commission and national case handlers working from home, not rendering working conditions any easier.

From a legal perspective, commentators have been describing the process as 'constructing the railway with the train already on it'. Never before has the EU been faced with such a situation, and both national authorities and the Commission have gained new insights along the way. This is also reflected in the legislative history of the TF. Issued on 19 March, the TF was first amended only two weeks later, on 3 April, and a second amendment was made on 8 May. Each amendment added new sections on new types of aid, but it also introduced changes and/or 'clarifications' to the existing sections, eg relating to the notion of 'firm in difficulty', rules on 
cumulation, the handling of aid to financial institutions, the types of measures allowed under TF 3.1., assessment of the liquidity needs under TF 3.2 and 3.3., etc.

This issue of EStAL boasts a number of interesting articles and country reports on State aid issues linked to tackling COVID-19, both from a legal, economic, and regulatory perspective.

As also illustrated by the recent COVID-19 e-conference held by Lexxion on 12 June 2020, boasting prominent speakers from the European Commission, from national authorities and from private practice, the legal issues at stake are plentiful. It goes beyond the scope of this editorial to dive into each of these issues, so I will limit myself to three 'hot topics'.

\section{Topic 1: Undertakings Already in Difficulty by 31 December 2019}

First, many authorities and companies have struggled with the general TF requirement that aid must not be granted to 'undertakings that were already in difficulty [...] by 31 December 2019'.

The Commission has later clarified that this does not exclude companies that were in difficulty by that date (eg due to the capital loss requirement), but that have recovered before the date of the grant.

Also, how to assess a group of companies with eg a parent company being in difficulty and a subsidiary not being in difficulty or vice versa? Should reference be made to the notion of a 'single undertaking' (known from classic merger cases and to some extent reflected in the SME Notice), or should one rather rely on the notion of 'economic activity', where one looks not at the legal constructions, but rather the activities carried out? After all, an 'undertaking' is defined by the economic activity carried out, regardless of the legal status and its way of financing.

Interestingly, judging from the remarks made during the aforementioned conference on 12 May, the Commission seems to have opted for the 'single undertaking' approach, implying identification between group related entities. This means that a 'healthy' subsidiary can never receive aid under the TF if it has an 'unhealthy' parent. On the other hand, it would seem that a healthy parent company can receive aid under the TF if the subsidiary is 'unhealthy', provided that appropriate safeguards are introduced to ensure arm's length or ring-fencing of the aid so that the aid does not flow to the subsidiary. Further clarification on this issue would be welcome - and is expected in Case SA.57405 (decision of 26 May re. Groupe Novares, not yet published).

\section{Topic 2: Checks for Overcompensation - Article 107(2)(b) versus Article 107(3)(b) TFEU}

Second, it has been queried to which extent the TF requires checks for market failure, appropriateness and proportionality - to avoid eg companies being overcompensated and markets from being unnecessarily distorted. After all, TF point 19 does require Member States to show to the Commission that the State aid measures are 'necessary, appropriate and proportionate'. Moreover, the TF allows aid to both large undertakings and SMEs. The simple answer is that no such checks are required by the Commission, at least not when it comes to the (until now) most frequently used sections of the TF (sections 3.1. - 3.3.). Those sections set out a list of 
specific conditions, none of which include a requirement to identify the actual loss suffered by the companies or a prohibition against overcompensation. Hence, in principle, aid can be granted to companies potentially unaffected by (or even doing better as a result of) the COVID-19 crisis. In practice, most Member States have introduced additional requirements to ensure that aid is only disbursed to those needing it - which has given rise to interesting interpretative questions under national law.

The relatively large room for manoeuvre offered by the TF is in stark contrast with the rules on disaster aid granted under Article 107(2)(b) where a clear causal link between the crisis and the loss must be established and no overcompensation must occur. Since the latter requirement can be very difficult to enforce as long as the full extent of the crisis is not yet known, the Commission has accepted a model whereby the Member States carry out such checks for overcompensation at a later stage, including a repayment ('claw-back') mechanism.

On that note, this is reportedly the first time where Article 107(2)(b) aid is applied in parallel with Article 107(3)(b) - as the two provisions normally cover different situations. The former provision is about urgent aid to victims of an extraordinary event (eg terror attacks or ash clouds) whilst the latter provision is concerned with a 'serious disturbance in the entire economy'. COVID-19 checks both boxes.

An interesting side-question here is of course how long Article 107(2)(b) TFEU can be applied. For how long will COVID-19 be an extraordinary event as opposed to a 'new normal' being part of normal business conditions (akin to the situation of airports adjusting their ways of conducting security checks after 9/11)? For how long is the 'counterfactual' the business conditions existing pre-COVID-19? An intriguing topic for lawyers, economists and policy makers in the months to come.

\section{Topic 3: Rules on Cumulation}

Third, the rules on cumulation in the TF are not always easy to understand, apply and enforce in practice. This is also reflected in the clarifications added to the TF on this issue (see eg new points 20 and 24bis). To illustrate the potential intricacy, it is possible for a company to receive aid amounts composed of both de minimis aid (up to $€ 200,000$ ), TF 3.1.-aid (up to $€ 800,000$ ), TF 3.3-aid (eg $€ 2$ million in the specific case), and start-up aid under GBER Article 22 (up to $€_{4}$ million for a 5-year loan to small innovative companies).

Given the many different aid instruments available during these days, the above example is not entirely hypothetical and triggers an interesting question of monitoring and enforcement.

Some Member States (eg Greece) have central registers where all aid (amounts and aid instruments) is being listed - and not just the $+€_{500,000}$ aid which must be reported to the Commission under GBER.

But this is certainly not the case in other Member States, where the authorities make aid beneficiaries sign a solemn declaration that rules on cumulation are respected and then trust the companies to understand, store and apply this information in later cases. This is often an illusion. In our experience, an SME is rarely aware of the legal basis of the aid received (eg TF sections 3.1. or 3.3. where it is instrumental to check for cumulation later on) and is also incapable of conducting a complex assessment of whether the cumulated aid amounts are too high (eg combining GBER and the TF, but possibly also combining eg TF 3.1. and 3.3.). 
For this reason, Member States should be applauded and encouraged for introducing streamlined procedures for tracking and reporting all aid into a central State aid register - to ensure that companies are not inadvertently overcompensated with the risk of facing serious and potentially life-threatening recovery claims.

Let us not forget, in this context, that claims for repayment must be brought at the initiative (ex officio) of the national authorities, cf Case C-349/17 Eesti Pagar, without the need for a complainant to bring a case before the Commission.

Thus, the same authorities will potentially both act as 'offenders' (granting too much aid) and as law enforcers (actively seeking recovery of such aid). With the extra twist that, in the State aid universe, aid must be paid back to the very Member State having offended the law with interest. While this is one of the well-known principles of State aid enforcement which this author has learned to accept, the good intentions of the Member States will be for naught if the aid granted by them to businesses struggling due to the pandemic would come with unexpected strings attached in the form of a devastating repayment claim.

Enjoy your reading!

Michael Honoré*

* Michael Honoré, Partner at Honoré \& Fallesen, Copenhagen (<https://www.honorefallesen.dk/>), Lexxion Academic Director and Member of the EStAL Editorial Board. For correspondence: <mih@honorefallesen.dk>. 